$$
\begin{aligned}
& \text { RECEIVED } \\
& \text { MAY }{ }_{2} 1997 \\
& \text { OSTI }
\end{aligned}
$$
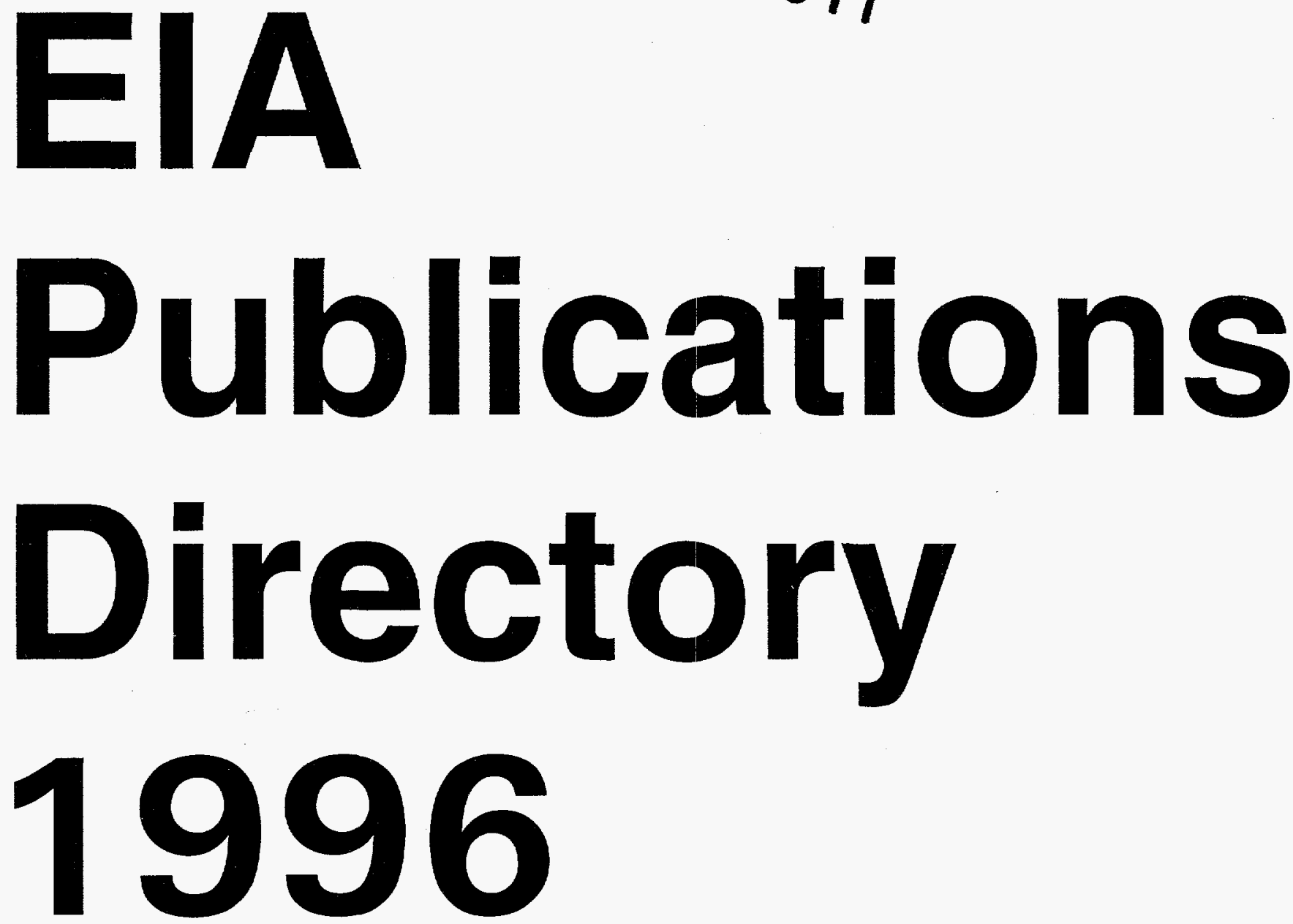

May 1997 Distramon of nes Dergy Information Administration 


\section{HOW TO OBTAIN EIA PRODUCTS AND SERVICES}

For further information on any of the following services, or for answers to energy information questions, please contact EIA's National Energy Information Center:

National Energy Information Center (NEIC)

(202) 586-8800

Energy Information Administration

(202) 586-0727 (fax)

Forrestal Building, Room 1F-048

TTY: (202) 586-1181

Washington, DC 20585

E-mail: infoctr@eia.doe.gov

\section{Electronic Products and Services}

EIA's Internet Site Services offer nearly all EIA publications. Users can view and download selected pages or entire reports, search for information, download EIA data and analysis applications, and find out about new EIA information products and services.

World Wide Web: http://www.eia.doe.gov

Gopher: gopher://gopher.eia.doe.gov

FTP: ftp://ftp.eia.doe.gov

EIA also offers a listserve service for EIA press releases and other short documents. Sign up on the EIA World Wide Web site.

EIA's CD-ROM, Energy InfoDisc, contains most EIA publications, several databases, and an energy forecasting model. The Energy InfoDisc, produced quarterly, is available for a fee from STAT-USA, Department of Commerce, 1-800-STAT-USA.

The Comprehensive Oil and Gas Information Source (COGIS), a bulletin board service, contains data files from most of EIA's oil-and gas-related reports. It is available for a fee from STAT-USA, on 1-800-STAT-USA.

EIA's Electronic Publishing System (EPUB) bulletin board contains data files, directories, and forecasts from most EIA reports. It can be accessed free of charge by dialing (202) 586-2557.

Many of EIA's data files and modeling programs are available for sale on diskette, tape, or cartridge, through either the National Technical Information Service or the Office of Scientific and Technical Information, Department of Energy. Contact NEIC for information on specific products, sources, and media, and ordering instructions.

\section{Printed Publications}

EIA directories are available free of charge from NEIC. Recent periodicals and one-time reports are available from the Government Printing Office. Older reports are available from the National Technical Information Service:

Superintendent of Documents

U.S. Government Printing Office

P.O. Box 371954

Pittsburgh, PA 15250-7954

(202) $512-1800$; (202)-512-2250 (fax)
National Technical Information Service

U.S. Department of Commerce

Springfield, VA 22161

5285 Port Royal Road

(703) $487-4650$; (703) 321-8547 (fax) 


\section{DISCLAMMER}

Portions of this document may be illegible in electronic image products. Images are produced from the best available original document. 


\section{DISCLAIMER}

This report was prepared as an account of work sponsored by an agency of the United States Government. Neither the United States Government nor any agency thereof, nor any of their employees, make any warranty, express or implied, or assumes any legal liability or responsibility for the accuracy, completeness, or usefulness of any information, apparatus, product, or process disclosed, or represents that its use would not infringe privately owned rights. Reference herein to any specific commercial product, process, or service by trade name, trademark, manufacturer, or otherwise does not necessarily constitute or imply its endorsement, recommendation, or favoring by the United States Government or any agency thereof. The views and opinions of authors expressed herein do not necessarily state or reflect those of the United States Government or any agency thereof. 
DOE/EIA-0149(96)

Distribution Category UC-950

\title{
EIA Publications Directory 1996
}

\author{
May 1997
}

\author{
Energy Information Administration \\ National Energy Information Center \\ U.S. Department of Energy \\ Washington, DC 20585
}

This report was prepared by the Energy Information Administration, the independent statistical and analytical agency within the Department of Energy. The information contained herein should not be construed as advocating or reflecting any policy position of the Department of Energy or any other organization. 


\section{Preface}

Enacted in 1977, the Department of Energy (DOE) Organization Act established the Energy Information Administration (EIA) as the Department's independent statistical and analytical agency, with a mandate to collect and publish data and prepare analyses on energy production, consumption, prices, resources, and projections of energy supply and demand. This edition of the EIA Publications Directory contains titles and abstracts of periodicals and one-time reports produced by EIA from January through December 1996.
The body of the Directory contains citations and abstracts arranged by broad subject categories; metadata, coal, oil and gas, nuclear, electricity, renewable and energy/alternative fuels, multifuel, end-use consumption, models, and forecasts.

Questions concerning publications in the Directory should be directed to the National Energy Information Center (NEIC) at (202) 5868800 .

Comments on the Directory itself should be directed to Karen Freedman at (202) 586-9254. 


\section{How to Use the EIA Publications Directory}

Availability. This directory contains abstracts and brief ordering information for individual issues of semiannual, annual, biennial, and triennial periodicals, analysis reports, Service Reports, and model documentation. (Service Reports are prepared by EIA upon special request and may be based on assumptions specified by the requestor.) Most publications are available from the National Technical Information Service (NTIS), U.S. Department of Commerce. Contact NTIS at (703) 487-4650 for all specific ordering information.

Periodicals produced more frequently than semiannually -- quarterlies, monthlies, and weeklies -- are listed as single titles. Individual issues are not listed, and no ordering information is given. If the periodical is current, it is available by subscription from the U.S. Government Printing Office (GPO). Contact GPO at (202) $512-1800$.

Some recent individual issues are also available from GPO. Most recent issues of current and discontinued periodicals are available from NTIS. For ordering information regarding these periodicals, call NTIS directly. Annual and one-time reports which are available from GPO are indicated with a GPO stock number and price.

Abstracts. Publication abstracts are arranged by abstract number within subject categories as listed in the table of contents.

Subject Index. The subject index is arranged alphabetically by specific energy terminology. The numbers that follow each entry refer the reader to the related publication abstract. 


\section{Contents}

Page

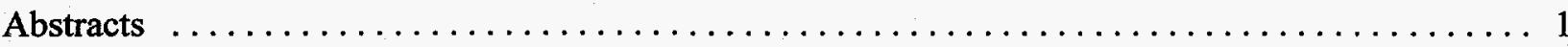

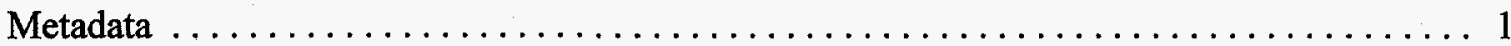

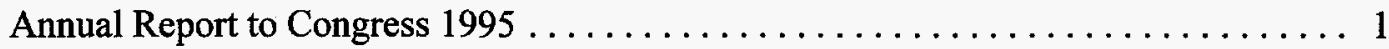

Directory of Energy Data Collection Forms $1995 \ldots \ldots \ldots \ldots \ldots \ldots \ldots \ldots \ldots$

Directory of Energy Data Collection Forms $1996 \ldots \ldots \ldots \ldots \ldots \ldots \ldots \ldots$

Directory of Energy Information Administration Models $1996 \ldots \ldots \ldots \ldots \ldots \ldots 1$

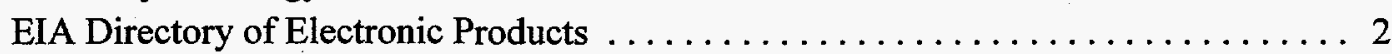

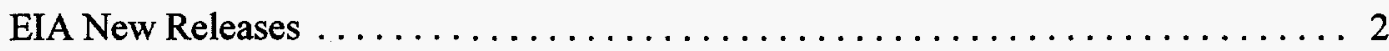

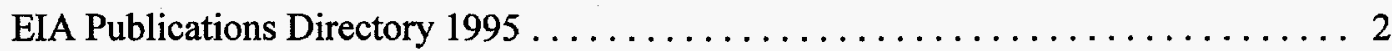

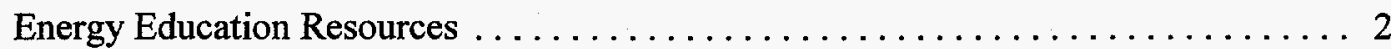

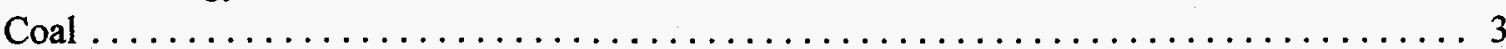

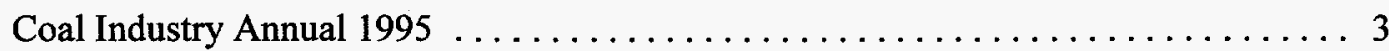

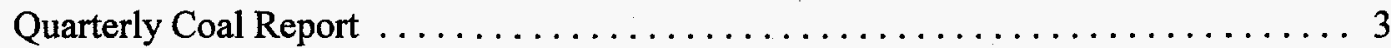

U.S. Coal Reserves: A Review and Update ..................... 3

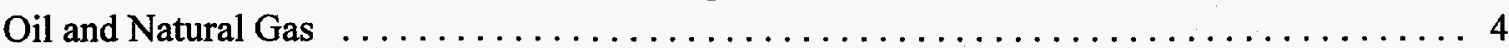

Costs and Indices for Domestic Oil and Gas Field Equipment and Production Operations 1992 Through $1995 \ldots \ldots \ldots \ldots \ldots \ldots \ldots$

A Guide to Surveys of Motor Vehicle Fleets $\ldots \ldots \ldots \ldots \ldots \ldots \ldots \ldots$

Fuel Oil and Kerosene Sales $1995 \ldots \ldots \ldots \ldots \ldots \ldots \ldots \ldots \ldots \ldots \ldots$

The Impacts on U.S. Energy Markets and the Economy of

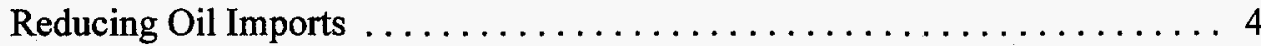

International Petroleum Statistics Report $\ldots \ldots \ldots \ldots \ldots \ldots \ldots \ldots \ldots \ldots$

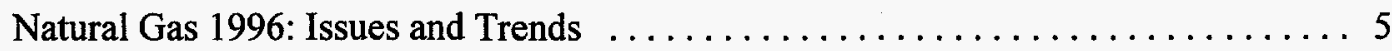

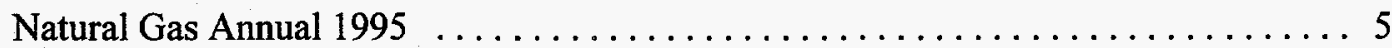

Natural Gas Monthly ............................. 5

Natural Gas Productive Capacity for the Lower 48 States

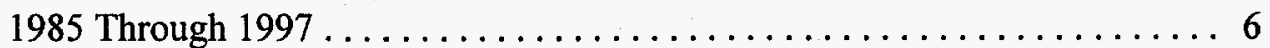

Oil Production Capacity Expansion Costs for the Persian Gulf $\ldots \ldots \ldots \ldots \ldots \ldots$

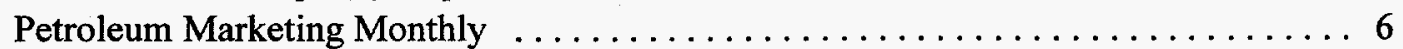

Petroleum Supply Annual 1995, Volume $1 \ldots \ldots \ldots \ldots \ldots \ldots \ldots \ldots \ldots \ldots$

Petroleum Supply Annual 1995, Volume $2 \ldots \ldots \ldots \ldots \ldots \ldots \ldots \ldots \ldots \ldots \ldots \ldots \ldots \ldots$

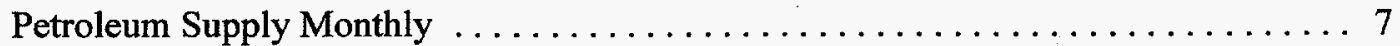

U.S. Crude Oil, Natural Gas, and Natural Gas Liquids Reserves

1995 Annual Report . . . . . . . . . . . . . . . . . . . . . . 8

Weekly Petroleum Status Report $\ldots \ldots \ldots \ldots \ldots \ldots \ldots \ldots \ldots \ldots \ldots \ldots$

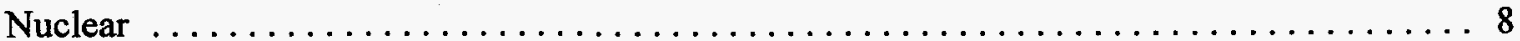

Nuclear Power Generation and Fuel Cycle Report $1996 \ldots \ldots \ldots \ldots \ldots \ldots \ldots \ldots 8$

Spent Nuclear Fuel Discharges from U.S. Reactors $1994 \ldots \ldots \ldots \ldots \ldots \ldots \ldots \ldots$. . . . . 9

Uranium Industry Annual $1995 \ldots \ldots \ldots \ldots \ldots \ldots \ldots \ldots$

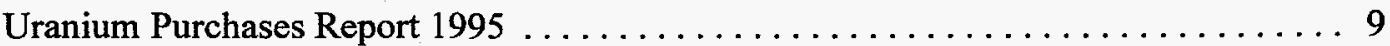

Energy Information Administration/EIA Publications Directory $1996 \quad$ V 
An Analysis of FERC's Final Environmental Impact Statement

for Electricity Open Access and Recovery of Stranded Costs . . . . . . . . 10

Electric Power Annual 1995, Volume I . . . . . . . . . . . . . . . . . . . . . . 10

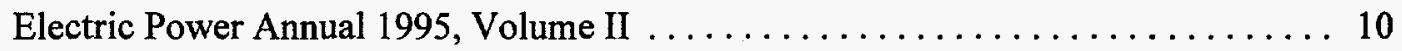

Electric Power Monthly . . . . . . . . . . . . . . . . . . . . 11

A Review of FERC's Final Environmental Impact Statement

for Electricity Open Access and Recovery of Stranded Costs . . . . . . . . 11

Renewable Energy \&

Alternative Fuels $\ldots \ldots \ldots \ldots \ldots \ldots \ldots \ldots \ldots \ldots \ldots \ldots \ldots \ldots \ldots \ldots \ldots$

Alternatives to Traditional Transportation Fuels 1994, Volume $1 \ldots \ldots \ldots \ldots \ldots 11$

Alternatives to Traditional Transportation Fuels 1994, Volume 2:

Greenhouse Gas Emissions . . . . . . . . . . . . . . . . 12

Alternatives to Traditional Transportation Fuels $1995 \ldots \ldots \ldots \ldots \ldots \ldots \ldots \ldots \ldots$

Multifuel ......................................... 12

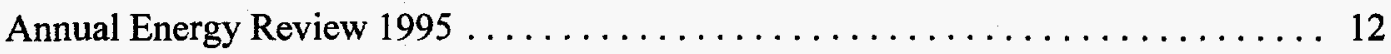

Emissions of Greenhouse Gases in the United States $1995 \ldots \ldots \ldots \ldots \ldots \ldots$

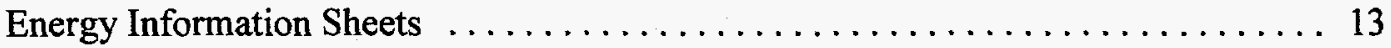

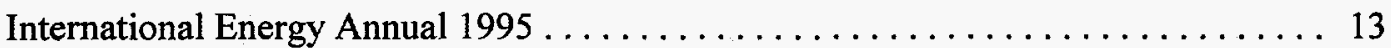

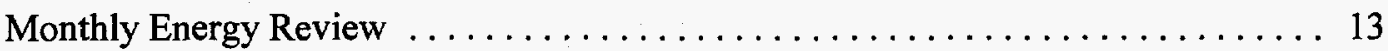

The National Energy Modeling System: An Overview . . . . . . . . . . . 14

Performance Profiles of Major Energy Producers $1994 \ldots \ldots \ldots \ldots \ldots \ldots \ldots \ldots$

Privatization and the Globalization of Energy Markets $\ldots \ldots \ldots \ldots \ldots \ldots \ldots \ldots$

State Energy Data Report 1994 Consumption Estimates . . . . . . . . . . . 15

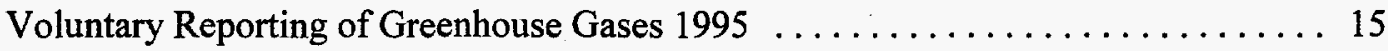

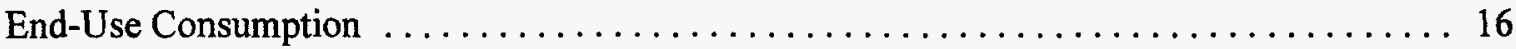

Energy Consumption Series Residential Energy Consumption

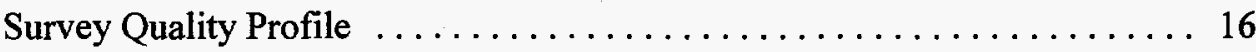

Energy Consumption Series Residential Lighting: Use and Potential Savings . . . 16

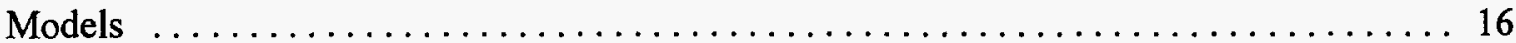

Documentation of the Oil and Gas Supply Module (OGSM) . . . . . . . . 16

Electricity Market Module Electricity Capacity Planning Submodule -

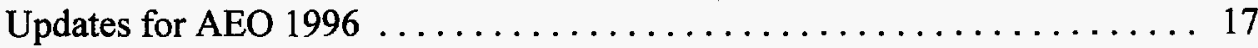

Electricity Market Module Electricity Finance and Pricing Submodule -

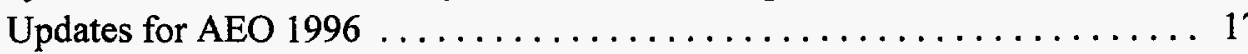

Electricity Market Module Electricity Fuel Dispatch Submodule -

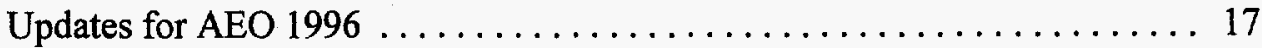

EIA Model Documentation: Petroleum Market Model of the National

Energy Modeling System . . . . . . . . . . . . . . . . 17

Model Documentation Coal Market Module of the National Energy

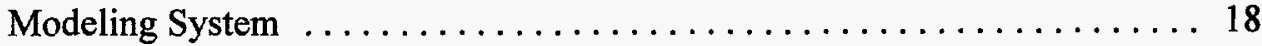

Model Documentation Natural Gas Transmission and Distribution

Model of the National Energy Modeling System - Volume I . . . . . . . 18

Model Documentation Renewable Fuels Module of the National

Energy Modeling System . . . . . . . . . . . . . . . . . . . 19 
Model Documentation Report Short-Term Hydroelectric Generation Model ..... 19

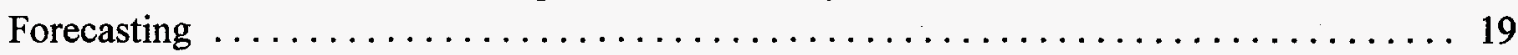

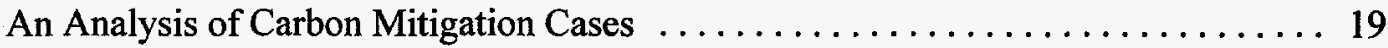

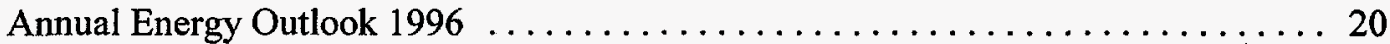

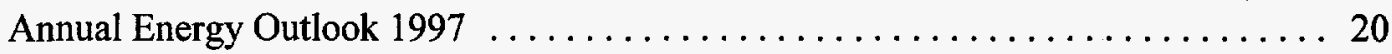

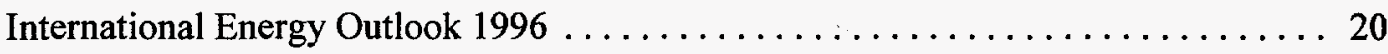

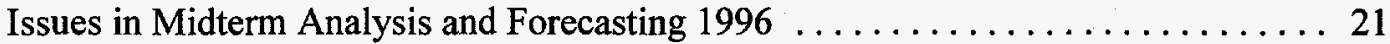

Short-Term Energy Outlook Quarterly Projections $\ldots \ldots \ldots \ldots \ldots \ldots \ldots \ldots 21$

Energy Information Administration's Products and Services $\ldots \ldots \ldots \ldots \ldots \ldots \ldots \ldots \ldots \ldots \ldots$

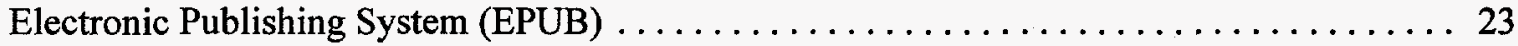

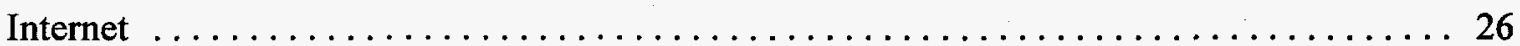

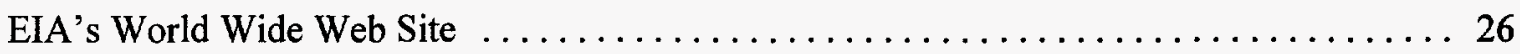

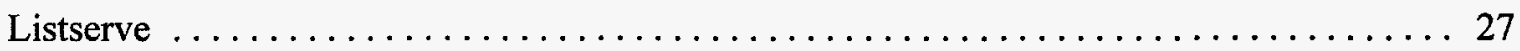

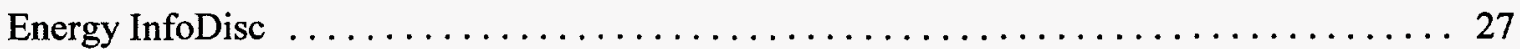

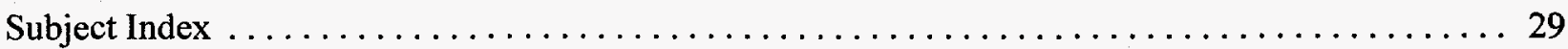

How to Order from the National Energy Information Center $\ldots \ldots \ldots \ldots \ldots \ldots \ldots \ldots \ldots \ldots$

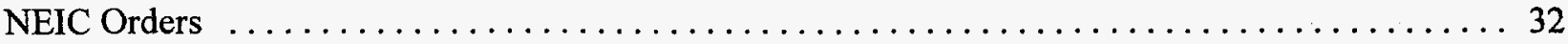




\section{Abstracts}

\section{Metadata}

\section{$1 \quad$ Annual Report to Congress 1995}

The Annual Report to Congress 1995 discusses accomplishments of the Energy Information Administration (EIA) and describes the functions and responsibilities of EIA. Active models and data collection surveys are described in the appendices along with a listing of publications and periodicals published during the year. During 1995, EIA worked hard to ensure efficient operations, cost effectiveness, and alignment of its product slate and services with customer requirements. EIA's Strategic Plan was developed, providing a road map for the remainder of the decade. While maintaining highpriority core programs and supporting new activities mandated by law, EIA moved to standardize core business systems through reengineering, to improve productivity through performance measurement and quality management, and to meet the needs of its customer base through the delivery of timely, innovative, customer-oriented products and services.

DOE/EIA-0173(95) Annual Jul $1996 \quad 68$ pp.

\section{Directory of Energy Data Collection Forms 1995}

This is the nineteenth edition of the Directory of Energy Data Collection Forms, an authoritative listing of selected public use forms currently used as basic energy information gathering tools by the Department of Energy (DOE). Originally entitled EIA Data Collection Forms, this directory provides an overview of DOE's energy information collection programs for decision makers in Government and industry. Forms designed to collect energy information and used by the Energy Information Administration (EIA) as of October 1995 are included in this directory. For each form listed in this directory, an abstract is included that describes the form's uses, its respondents, and the data collected.

DOE/EIA-0249(95) Annual Jan 199680 pp.

\section{Directory of Energy Data Collection Forms 1996}

This is the twentieth edition of the Directory of Energy Data Collection Forms, an authoritative listing of selected public use forms currently used as basic energy information gathering tools by the Department of Energy (DOE). Originally entitled EIA Data Collection Forms, this directory provides an overview of DOE's energy information collection programs for decision makers in Government and industry. Forms designed to collect energy information and used by the Energy Information Administration (EIA) as of October 31, 1996 are included in this directory. For each form listed in this directory, an abstract is included that describes the form's uses, its respondents, and the data collected.

DOE/EIA-0249(96) Annual Dec $199672 \mathrm{pp}$.

\section{Directory of Energy Information Administration Models 1996}

This directory revises and updates the Directory of Energy Information Administration Models 1995. Four models have been deleted in this directory as they are no longer used. This directory contains descriptions about each model, including the title, acronym, purpose, followed by 
more detailed information on characteristics, uses, and requirements. Sources for additional information are identified. Included in this directory are 33 EIA models active as of March 1, 1996. Models that run on personal computers are identified by "PC" as part of the acronym. The models are divided into two groups and listed in alphabetical order within those groups. The first group lists those models which are part of the National Energy Modeling System (NEMS). The second group lists all other EIA models that are not part of NEMS.

DOE/EIA-0293(96) Annual Jul 199696 pp.

\section{$5 \quad$ EIA Directory of Electronic Products}

The EIA Directory of Electronic Products lists EIA machine-readable data files and computer models. The data files and models are made available to the public on magnetic tapes. In addition, selected data files/models are available on diskette for IBM-compatible personal computers. Selected data files and publications of EIA are accessible on-line and via CD-ROM technology. EIA and the U.S. Department of Commerce offer on-line, electronic bulletin board access to EIA files, and the Department of Commerce also distributes a CD-ROM which contains selected EIA publications. For each product listed in this directory, a detailed abstract is provided which describes the data published. This directory was discontinued after the 4th Quarter 1995 issue.

\section{DOE/EIA-0569 Quarterly Available: NEIC}

\section{$6 \quad$ EIA New Releases}

The latest available EIA publications and upcoming reports are listed and described in this quarterly publication (beginning with the 1st Quarter 1996). Availability and ordering information are provided. News about EIA and other items of interest to users of EIA publications are also included.

DOE/EIA-0204 Quarterly Available: NEIC

EIA Publications Directory 1995

This directory contains abstracts and ordering information for EIA publications released in 1995. The abstracts are arranged by broad subject category such as coal, petroleum, natural gas, and electric power. A comprehensive subject index, a title index, and a report number index are included. Each entry gives the title, report number, publication frequency, date, number of pages, and ordering information.

DOE/EIA-0149(95) Annual Oct $1996 \quad 80$ pp.

\section{$8 \quad$ Energy Education Resources}

This publication is the result of a study undertaken by the National Energy Information Center (NEIC), a service of EIA, to provide its customers with a list of generally available free or low-cost energy-related educational materials for students and educators. This list is updated once a year. Some organizations now make their products available via computer. When available, Internet (Web) and electronic mail (E-mail) addresses were included in this year's edition. Each entry is followed by a number, which is referenced in the subject index in the back of the book.

DOE/EIA-0546(95) Annual Mar $1996112 \mathrm{pp}$. 


\section{Coal}

\section{$9 \quad$ Coal Industry Annual 1995}

Coal Industry Annual 1995 provides comprehensive information about U.S. coal production, number of mines, prices, productivity, employment productive capacity, and recoverable reserves. This report presents data on coal consumption, coal distribution, coal stocks, coal prices, coal quality, and emissions for Congress, Federal and State agencies, the coal industry, and the general public. This report does not include coal consumption data for nonutility power producers that are not in the manufacturing, agriculture, mining, construction, or commercial sectors.

DOE/EIA-0584(95) Annual Oct 1996276 pp. GPO Stock Number: 061-003-00974-3

GPO Price: $\$ 22.00$

\section{Quarterly Coal Report}

The Quarterly Coal Report (QCR) provides comprehensive information about U.S. coal production, distribution, exports, imports, receipts, prices, consumption, distribution, and stocks to a wide audience, including Congress, Federal and State agencies, the coal industry, and the general public. Coke production, consumption, distribution, imports, and exports data are also provided.

\section{DOE/EIA-0121 Quarterly GPO Subscription}

Price: $\$ 28.00$

\section{U.S. Coal Reserves: A Review and Update}

Section 205(a)(2) of the Department of Energy Organization Act of 1977 (Public Law 95-91) requires the Administrator of the Energy Information Administration (EIA) to carry out a central, comprehensive, and unified energy data information program to collect, evaluate, assemble, analyze, and disseminate data and information relevant to energy resources, reserves, production, demand, technology, and related economic and statistical information. This report, U.S. Coal Reserves: A Review and Update, is the third in a series of "U.S. Coal Reserves" reports. As part of the EIA program to provide information on coal, it presents detailed estimates on domestic coal reserves, which are basic to the analysis and forecasting of future coal supply. It also describes the data, methods, and assumptions used to develop such estimates and explains terminology related to recent data programs. In addition, the report provides technical documentation for specific revisions and adjustments to the demonstrated reserve base (DRB) of coal in the United States and for coal quality and reserve allocations. It makes the resulting data available for general use by the public. This report includes data on recoverable coal reserves located at active mines and on the estimated distribution of rank and sulfur content in those reserves. An analysis of the projected demand and depletion in recoverable reserves at active mines is used to evaluate the areas and magnitude of anticipated investment in new mining capacity.

DOE/EIA-0529(95) One-Time Aug 1996 116 pp. GPO Stock Number: 061-003-00967-1 GPO Price: $\$ 9.50$ 


\section{Oil and Natural Gas}

\section{Costs and Indices for Domestic Oil and Gas Field Equipment and Production Operations 1992 Through 1995}

This is the thirteenth report in the series on domestic costs and indices for oil and gas field equipment and production operations. The purpose of the series is to provide a continuing means of gauging changes in the oil and gas producing industry's costs. The last report in this series, which reported data from 1990 through 1993, had report number DOE/EIA-TR0568. This report returns to the prior report series nomenclature, DOE/EIA-0185(95). The cost data presented in this report are used by government agencies, the academic community, and the oil and gas industry.

DOE/EIA-0185(95) Biennial Aug 1996124 pp. GPO Stock Number: 061-003-00968-9

GPO Price: $\$ 9.50$

\section{A Guide to Surveys of Motor Vehicle Fleets}

In response to directives in Section 407 of the Energy Policy Act of 1992 (EPACT), the Energy Information Administration (EIA) developed a data collection program designed to provide information useful to persons interested in the alternative fuels market. The target audience includes those seeking to manufacture, convert, sell, own, or operate alternative-fueled vehicles (AFV's) or alternative fueling facilities. The procedures outlined in this report are, for the most part, the procedures used for the fleet survey conducted in Denver, Colorado. There were several enhancements in the survey process instituted between the survey in Atlanta, Georgia, and the one in Denver. These enhancements resulted in a more efficient and reliable survey.

DOE/EIA-0610 One-Time Nov 199632 pp.

\section{Fuel Oil and Kerosene Sales 1995}

This publication contains the 1995 survey results of the "Annual Fuel Oil and Kerosene Sales Report" (Form EIA-821). This is the seventh year that the survey data have appeared in a separate publication. Prior to the 1989 report, the statistics appeared in the Petroleum Marketing Annual for reference year 1988 and the Petroleum Marketing Monthly for reference years 1984 through 1987. The 1995 edition marks the 12th annual presentation of the results of the ongoing "Annual Fuel Oil and Kerosene Sales Report" survey.

DOE/EIA-0535(95) Annual Sep $1996 \quad 64$ pp. GPO Stock Number: 061-003-00970-1

GPO Price: $\$ 5.00$

\section{The Impacts on U.S. Energy Markets and the Economy of Reducing Oil Imports}

This study was undertaken at the request of the General Accounting Office (GAO). Its purpose is to evaluate the impacts on U.S. energy markets and the economy of reducing oil imports. The approach and assumptions underlying this report were specified by GAO and are attached as an Appendix. The study focuses on two approaches: (1) a set of cases with alternative world crude oil price trajectories and (2) two cases which investigate the use of an oil import tariff to achieve a target reduction in the oil imports. The analysis presented uses the National Energy 
Modeling System, which is maintained by the Office of Integrated Analysis and Forecasting within the Energy Information Administration (EIA), and the DRI/McGraw Hill Macroeconomic Model of the U.S. Economy, a proprietary model maintained by DRI and subscribed to by EIA.

DOE/EIA-SR/OIAF(96-04) One-Time Sep 1996 $52 \mathrm{pp}$.

\section{International Petroleum Statistics Report}

The International Petroleum Statistics Report (ISPR) is a monthly publication that provides current international oil data. This report is published for the use of Members of Congress, Federal and State agencies, industry, and the general public. This report presents data on international oil production, demand, imports, and stocks. The report has four sections. Section 1 contains time series data on world oil production, and on oil demand and stocks in the Organization for Economic Cooperation and Development (OECD). This section contains annual data beginning in 1985, and monthly data for the most recent two years. Section 2 presents an oil supply/demand balance for the world. This balance is presented in quarterly intervals for the most recent two years. Section 3 presents data on oil imports by OECD countries. This section contains annual data for the most recent year, quarterly data for the most recent two quarters, and monthly data for the most recent twelve months. Section 4 presents annual time series data on world oil production and oil stocks, demand, and trade in OECD countries.

DOE/EIA-0520 Monthly GPO Subscription Price: $\$ 50.00$

\section{Natural Gas 1996: Issues and Trends}

Natural Gas 1996: Issues and Trends focuses on the increasing choices available to participants in the natural gas industry, from suppliers to consumers, at a time when regulatory restraints increasingly are removed from the sale and transport of natural gas. The industry faces significant challenges, such as how to deal with price volatility. In addition, cost-conscious suppliers, marketers, distributors, and consumers now pay increased attention to inventory levels and reducing excess capacity and stocks.

DOE/EIA-0560(96) Annual Dec 1996188 pp. GPO Stock Number: 061-003-00979-4

GPO Price: $\$ 16.00$

\section{$18 \quad$ Natural Gas Annual 1995}

The Natural Gas Annual 1995 (NGA) provides information on the supply and disposition of natural gas to a wide audience including industry, consumers, Federal and State agencies, and educational institutions. The 1995 data are presented in a sequence that follows natural gas (including supplemental supplies) from its production to its end use. This is followed by tables summarizing natural gas supply and disposition from 1991 to 1995 for each Census Division and each State. Annual historical data are shown at the national level.

DOE/EIA-0131(95) Annual Nov 1996264 pp. GPO Stock Number: 061-003-00976-0

GPO Price: $\$ 21.00$

\section{Natural Gas Monthly}

The Natural Gas Monthly (NGM) highlights activities, events, and analyses of interest to public and private sector organizations associated with the natural gas industry. Volume and price 
data are presented each month for natural gas production, distribution, consumption, and interstate pipeline activities. Producer-related activities and underground storage data are also reported.

DOE/EIA-0130 Monthly GPO Subscription Price: $\$ 82.00$

\section{Natural Gas Productive Capacity for the Lower 48 States 1985 Through 1997}

The Natural Gas Productive Capacity for the Lower 48 States 1985 Through 1997 is the fifth in this series of reports. This publication is used by the Congress, Federal and States agencies, industry, and other interested parties to obtain accurate data of the lower 48 States' natural gas production history and wellhead productive capacity. Total demand for natural gas in the United States is met by a combination of natural gas production, underground gas storage, imported gas, and supplemental gaseous fuels. This report examines the natural gas production element of the total gas demand. Domestic natural gas production supplies the majority of the natural gas demand requirements for the lower 48 States. The production requirement continues to increase while drilling has remained at low levels, a fact that has raised some concern about the adequacy of future gas supplies, and gas producers' ability to meet periods of peak heating or cooling demand.

DOE/EIA-0542(97) Annual Dec 1996112 pp. GPO Stock Number: 061-003-00985-9

GPO Price: $\$ 13.00$

\section{Oil Production Capacity Expansion Costs for the Persian Gulf}

Oil Production Capacity Expansion Costs for the Persian Gulf provides estimates of development and operating costs for various size fields in countries surrounding the Persian Gulf. In addition, a forecast of the required reserve development and associated costs to meet the expected demand through the year 2010 is presented. This report takes a different approach than that normally seen in the literature. Results are based on geologic plays and their individual development costs rather than country-level economics. Petroconsultants Estimator database and software provided the cost data and field properties on which this analysis is based.

DOE/EIA-TR/0606 One-Time Feb 199636 pp. GPO Stock Number: 061-003-00953-1

GPO Price: $\$ 2.75$

\section{$22 \quad$ Petroleum Marketing Monthly}

The Petroleum Marketing Monthly (PMM) provides information and statistical data on a variety of crude oils and refined petroleum products. The publication presents statistics on crude oil costs and refined petroleum products sales for use by industry, government, private sector analysts, educational institutions, and consumers. Data on crude oil include the domestic first purchase price, and the f.o.b. and landed cost of imported crude oil. Refined petroleum product sales include motor gasoline, distillates, residuals, aviation fuels, kerosene, and propane.

DOE/EIA-0380 Monthly GPO Subscription Price: $\$ 94.00$ 


\section{Petroleum Supply Annual 1995, Volume 1}

The Petroleum Supply Annual 1995, Volume 1 (PSA) contains information on the supply and disposition of crude oil and petroleum products. The publication reflects data that were collected from the petroleum industry during 1995 through monthly surveys. This first volume contains three sections: Summary Statistics, Detailed Statistics, and selected Refinery Statistics each with final annual data. The summary statistics section contains a summary of the data presented each month in the Petroleum Supply Monthly (PSM). It includes a description of the major events in the petroleum industry during 1995 including trends in supply, consumption, and production. Graphs and tables are provided which show 15 years of data depicting the balance between supply, disposition and ending stocks for various commodities including crude oil, motor gasoline, distillate fuel oil, residual fuel oil, jet fuel, propane/propylene, and liquefied petroleum gases. The detailed statistics section provides 1995 detailed statistics on supply disposition, refinery operations, imports and exports, stocks, and transportation of crude oil and petroleum products. In most cases, the statistics are presented for several geographic areas -- the United States (50 States and the District of Columbia), five Petroleum Administration for Defense (PAD) Districts, and 12 Refining Districts. At the U.S. and PAD District level, the total volume and the daily rate of activities are presented.

DOE/EIA-0340(95)/1 Annual May 1996144 pp. GPO Stock Number: 061-003-00958-1

GPO Price: $\$ 11.00$

\section{Petroleum Supply Annual 1995, Volume 2}

The Petroleum Supply Annual 1995, Volume 2 (PSA) contains information on the supply and disposition of crude oil and petroleum products. The publication reflects data that were collected from the petroleum industry during 1995 through monthly surveys. This second volume contains final statistics for each month of 1995, and replaces data previously published in the Petroleum Supply Monthly (PSM). The tables in Volumes 1 and 2 are similarly numbered to facilitate comparison between them. Explanatory Notes, located at the end of the publication, present information describing data collection, sources, estimation methodology, data quality control procedures, modifications to reporting requirements and interpretation of tables. Industry terminology and product definitions are listed alphabetically in the Glossary.

DOE/EIA-0340(95)/2 Annual May 1996608 pp. GPO Stock Number: 061-003-00960-3

GPO Price: $\$ 38.00$

\section{Petroleum Supply Monthly}

The Petroleum Supply Monthly (PSM) is one of a family of four publications reflecting different levels of data timeliness and completeness. Data presented in the $P S M$ describe the supply and disposition of petroleum products in the United States and major U.S. geographic regions. The data series describe production, imports and exports, inter-Petroleum Administration for Defense (PAD) District movements, and inventories by the primary suppliers of petroleum products in the United States (50 States and the District of Columbia). The reporting universe includes those petroleum sectors in primary supply. Included are: petroleum refiners, motor gasoline blenders, operators of natural gas processing plants and fractionators, inter-PADD transporters, importers, and major inventory 
holders of petroleum products and crude oil. When aggregated, the data reported by these sectors approximately represent the consumption of petroleum products in the United States.

DOE/EIA-0109 Monthly GPO Subscription Price: $\$ 85.00$

\section{U.S. Crude Oil, Natural Gas, and Natural Gas Liquids Reserves 1995 Annual Report}

The U.S. Crude Oil, Natural Gas, and Natural Gas Liquids Reserves 1995 Annual Report provides annual proved reserves estimates. The EIA annual reserves report series is the only source of comprehensive domestic proved reserves estimates. This publication is used by the Congress, Federal and State agencies, industry, and other interested parties to obtain accurate estimates of the Nation's proved reserves of crude oil, natural gas, and natural gas liquids. These data are essential to the development, implementation, and evaluation of energy policy and legislation. This report presents estimates of proved reserves of crude oil, natural gas, and natural gas liquids as of December 31,1995 , as well as production volumes for the United States and selected States and State subdivisions for 1995. Estimates are presented for the following four categories of natural gas: total gas (wet after lease separation), nonassociated gas and associated-dissolved gas (which are the two major types of wet natural gas), and total dry gas (wet gas adjusted for the removal of liquids at natural gas processing plants). In addition, reserve estimates for two types of natural gas liquids, lease condensate, and natural gas plant liquids, are presented.

DOE/EIA-216(95) Annual Nov 1996164 pp. GPO Stock Number: 061-003-00977-8

GPO Price: $\$ 14.00$

\section{Weekly Petroleum Status Report}

The Weekly Petroleum Status Report (WPSR) provides timely information on the petroleum supply situation in the context of historical information, selected price, and forecasts. The WPSR is intended to provide up-to-date information to the industry, the press, planners, policymakers, consumers, analysts, and State and local governments. Shown are the U.S. petroleum balance sheet, refinery activity, stocks, imports, products supplied, and prices. Data cover: refinery inputs, utilization, and production; stocks of crude oil and major products (gasoline, distillate fuel oil, residual fuel oil, etc.) by Petroleum Administration for Defense District; refiner acquisition cost of crude oil; retail selling prices for motor gasoline and residential heating oil; world crude oil prices; and spot market product prices. Strategic Petroleum Reserve data are shown when appropriate. Appendix A presents explanatory notes and Appendix B presents the results of Form EIA 819, "Monthly Oxygenate Telephone Report." Since discontinuing the EIA publication Winter Fuels Report after the 1995-1996 heating season, Appendix $\mathrm{C}$ in the WPSR now includes the Winter Heating Fuels Summary beginning with the 1996-1997 heating season.

DOE/EIA-0208 Weekly GPO Subscription Price: $\$ 83.00$

\section{Nuclear}

\section{Nuclear Power Generation and Fuel Cycle Report 1996}

The Nuclear Power Generation and Fuel Cycle Report 1996 presents the current status and projections through 2015 of nuclear capacity, generation, and fuel cycle requirements for all countries using nuclear power to generate 
electricity for commercial use. It also contains information and forecasts of developments in the worldwide nuclear fuel market. Long-term projections of U.S. nuclear capacity, generation, and spent fuel discharges for two different scenarios through 2040 are developed. A discussion on the decommissioning of U.S. nuclear power plants is presented. This report provides information to a wide audience, including the Congress, Federal and State agencies, the Organization for Economic Cooperation and Development, and the general public.

DOE/EIA-0436(96) Annual Oct $1996136 \mathrm{pp}$. GPO Stock Number: 061-003-00975-1

GPO Price: $\$ 11.00$

\section{Spent Nuclear Fuel Discharges from U.S. Reactors 1994}

Spent Nuclear Fuel Discharges from U.S. Reactors 1994 provides current statistical data on fuel assemblies irradiated at commercial nuclear reactors operating in the United States. This report provides data on the current inventories and storage capacities at these reactors. The report was prepared by the Energy Information Administration (EIA) under a Memorandum of Understanding with the Office of Civilian Radioactive Waste Management. The data are used by a wide audience, including Congress, Federal and State agencies, the nuclear and electric industries, and the general public. They also constitute one of the inputs to the Characteristics Data Base developed by Oak Ridge National Laboratory and maintained by TRW Environmental Safety Systems, Inc. The discharge dates, assembly types, burnups, and initial enrichments are used to calculate the gamma, neutron, and thermal source intensities. These radiological characteristics, along with reported fuel quantities and dimensions, are then used by the Civilian Radioactive Waste Management System designers in scoping studies for shielding design, thermal design, and sizing of facilities and equipment. This is the final issue of this publication.

DOE/EIA-SR/CNEAF/96-01 Service Report Feb 1996272 pp.

\section{$30 \quad$ Uranium Industry Annual 1995}

The Uranium Industry Annual 1995 (ULA) provides current statistical data on the U.S. uranium industry's activities relating to uranium raw materials and uranium marketing. The UIA is prepared for use by Congress, Federal and State agencies, the uranium and nuclear electric utility industries, and the public. It contains data for period 1986 through 2005 as collected on the Form EIA-858, "Uranium Industry Annual Survey". Data collected on the "Uranium Industry Annual Survey" provide a comprehensive statistical characterization of the industry's activities for the survey year and also include some information about industry's plans and commitments for the near-term future. Where aggregate data are presented in the UIA, care has been taken to protect the confidentiality of company-specific information while still conveying accurate and complete statistical data.

DOE/EIA-0478(95) Annual May 199676 pp. GPO Stock Number: 061-003-00959-0

GPO Price: $\$ 5.50$

\section{$31 \quad$ Uranium Purchases Report 1995}

The Uranium Purchases Report 1995 is the fourth in a series of annual publications required by the Energy Policy Act of 1992 (EPACT 1992). This information is required to be made available to the Congress annually. Data reported by domestic nuclear utility companies in their responses to the 1994 through 1995 "Uranium Industry Annual Survey," Form EIA-858, Schedule B, "Uranium Marketing Activities," are provided in response to 
the requirements in the EPACT 1992. Information published in this report are U.S. utility purchases of uranium and enrichment services by origin country and seller. The Appendix contains an explanation of Form EIA858 survey methodologies with emphasis on the processing of Schedule B data. Also, this report contains a glossary of terms and additional purchase information.

DOE/EIA-0570(95) Annual Jun 199612 pp.

GPO Stock Number: 061-003-00961-1

GPO Price: $\$ 1.50$

\section{Electricity}

\section{An Analysis of FERC's Final Environmental Impact Statement for Electricity Open Access and Recovery of Stranded Costs}

This report presents the results of the analysis using National Energy Modeling System (NEMS). It discusses the methodology used in NEMS, defines the cases reviewed, and describes the results with respect to changes in electricity trade, generation by fuel and emissions of nitrogen oxides (NOx).

DOE/EIA-SR/OIAF/96-03 One-Time Sep 1996 $40 \mathrm{pp}$.

\section{Electric Power Annual 1995, Volume I}

The Electric Power Annual 1995, Volume I (EPA) presents a summary of electric power industry statistics at national, regional and State levels. The objective of this publication is to provide industry decisionmakers, government policymakers, analysts, and the general public with data that may be used in understanding U.S. electricity markets. With a focus on U.S. electric utilities, Volume I contains final 1995 data on net generation and fossil fuel consumption, stocks, receipts, and cost. Volume I also contains preliminary 1995 data on generating unit capability, as well as estimates of retail sales of electricity, associated revenue, and the average revenue per kilowatthour of electricity sold. These estimates are based on a monthly sample (Form EIA-826, "Monthly Electric Utility Sales and Revenue Report with State Distribution"). Additionally, information on net generation from renewable energy sources and on the associated generating capability in included in Volume $\mathrm{I}$ of the $E P A$. These data are compiled from three statistical forms filed monthly and one form filed annually by electric utilities.

DOE/EIA-0348(95)/1 Annual Jul 199668 pp. GPO Stock Number: 061-003-00966-2

GPO Price: $\$ 5.00$

\section{Electric Power Annual 1995, Volume II}

The Electric Power Annual 1995, Volume II presents a summary of electric power industry statistics at national, regional, and State levels. The objective of this publication is to provide industry decisionmakers, government policymakers, analysts, and the general public with historical data that may be used in understanding U.S. electricity markets. Volume II presents annual summary statistics for the electric power industry, including information on both electric utilities and nonutility power producers. Included are the preliminary data for electric utility retail sales of electricity, associated revenue, and average revenue per kilowatthour of electricity sold and for electric utility financial statistics, environmental statistics, power transactions, and 
demand-side management. Final data for U.S. nonutility power producers on installed capacity and gross generation, as well as supply and disposition information, are provided in Volume II.

DOE/EIA-0348(95)/2 Annual Dec 1996152 pp. GPO Stock Number: 061-003-00986-7

GPO Price: $\$ 10.00$

\section{Electric Power Monthly}

The Electric Power Monthly (EPM) presents monthly electricity statistics for a wide audience including Congress, Federal and State agencies, the electric utility industry, and the general public. The purpose of this publication is to provide energy decisionmakers with accurate and timely information that may be used in forming various perspectives on electric issues that lie ahead. The EIA collected the information in this report to fulfill its data collection and dissemination responsibilities as specified in the Federal Energy Administration Act of 1974 (Public Law 93-275) as amended.

DOE/EIA-0226 Monthly GPO Subscription Price: $\$ 94.00$

\section{A Review of FERC's Final Environmental Impact Statement for Electricity Open Access and Recovery of Stranded Costs}

This report reviews the Environmental Impact Statement (EIS) prepared by the Federal Energy Regulatory Commission for electricity transmission system open access (RM95-8-000) and recovery of stranded costs (RM94-7-001) rules that were issued in 1995 and 1994, respectively. This review has three parts, 1) a summary of FERC's purpose, methodology, and key results, 2) a review of the assumptions used in the EIS, comparing them to historical trends and other forecasts, and 3) a discussion of the reasonableness of results, as well as issues that could change results. This review focuses on generation changes because of the key issue in nitrogen oxides (NOx) changes.

DOE/EIA-SR/OIAF/96-02 One-Time Jul 1996 $28 \mathrm{pp}$.

\section{Renewable Energy \& Alternative Fuels}

\section{Alternatives to Traditional Transportation Fuels 1994, Volume 1}

Alternatives to Traditional Transportation Fuels 1994 is the second in a series of annual reports designed to provide data and information on alternative-fueled vehicles (AFV's) and alternative and replacement transportation fuels. Section 503(a) of the EPACT directs the Energy Information Administration (EIA) to estimate annually the number of AFV's in use in the United States, the amount and distribution of replacement fuel, and the greenhouse gas emissions likely to result from replacement fuel use. Section 503(b) directs suppliers of AFV's to report annually the number and type of AFV's made available in the previous year and those that the supplier plans to make available in the following year. Volume 1 of Alternatives to Traditional Transportation Fuels 1994 includes estimates of the number of AFV's in use (AFV inventory), estimates of alternative and replacement fuel consumption, and data on AFV's made available. The estimates are based on information as of October 1995.

DOE/EIA-0585(94)/1 Annual Feb $199681 \mathrm{pp.}$ GPO Stock Number: 061-003-00952-2 GPO Price: $\$ 4.25$ 


Alternatives to Traditional
Transportation Fuels 1994,
Volume 2: Greenhouse Gas
Emissions

This report provides information on greenhouse gases (GHG's) as required by Section 503 a(4) and $b(3)$ of the Energy Policy Act of 1992 (EPACT). Although EPACT is principally concerned with improving energy efficiency and curbing U.S. dependence on foreign oil, the requirement to estimate greenhouse gases reflects a desire that energy security not be promoted at the expense of the environment. Section 503 requires the Secretary of Energy, in consultation with the Administrator of the Energy Information Administration (EIA), to estimate GHG's emissions resulting from the use of the subset of replacement fuels know as "alternative transportation fuels." Further, EPACT requires an examination of GHG's over the entire fuel cycle rather than only those produced from combustion. EIA has decided to use the "Delucchi" fuel cycle approach because it offers the best framework for adhering to the EPACT requirements for estimating GHG's emissions from alternative transportation fuels, using gasoline as a comparison.

DOE/EIA-0585(94)/2 Annual Aug 199644 pp. GPO Stock Number: 061-003-00964-6

GPO Price: $\$ 2.50$

\section{Alternatives to Traditional Transportation Fuels 1995}

This report provides information on transportation fuels other than gasoline and diesel, and the vehicles that use these fuels. The Energy Information Administration (EIA) provides this information to support the U.S. Department of Energy's reporting obligations under Section 503 of the Energy Policy Act of 1992 (EPACT). The principal information contained in this report includes historical and year-ahead estimates of the following: (1) the number and type of alternativefueled vehicles (AFV's) in use; (2) the consumption of alternative transportation fuels and "replacement fuels" and; (3) the number and type of alternative-fueled vehicles made available in the current and following years. The alternative transportation fuels (ATF's) considered in this report are compressed natural gas (CNG), liquefied natural gas (LNG), liquefied petroleum gas (LPG, i.e. propane), methanol, ethanol, electricity, and biodiesel. Vehicles consuming these fuels may either be "new" AFV's or existing vehicles with converted fueling systems. Congress enacted EPACT with the objectives of lessening U.S. dependence on foreign petroleum and promoting energy efficiency. At the same time, EPACT requires that efforts to attain these objectives incorporate assessments of their consequences in regard to greenhouse gas production. Many have regarded the use of ATF's as a way to lessen dependency on foreign oil while simultaneously reducing greenhouse gas emissions.

DOE/EIA-0585(95) Annual Dec 199676 pp. GPO Stock Number: 061-003-00981-6

GPO Price: $\$ 7.50$

\section{Multifuel}

\section{$40 \quad$ Annual Energy Review 1995}

This fourteenth edition of the Annual Energy Review (AER) presents historical energy statistics. For most series, statistics are given for every year from 1949 through 1995. Because coverage spans four and a half decades, the statistics in this report are well-suited to long-term trend analyses. The $A E R$ is comprehensive. It covers all major energy statistics, including consumption, production, trade, stocks, and prices, for all major energy commodities, including fossil fuels and electricity. The $A E R$ also presents statistics on 
renewable energy sources. In the past, EIA's consumption series have included about half of the renewable energy used in the United States, the amount consumed by electric utilities. Last year, for the first time, usage by other consumers was integrated into EIA's historical consumption series for 1990 forward. Incorporation of nonelectric utility data into U.S. energy consumption adds about 3 quadrillion Btu to the total. For the most part, fuel-specific data in the $A E R$ are expressed in physical units, such as barrels, cubic feet, and short tons. The integrated summary data in Section 1 are expressed in Btu. Statistics expressed in Btu are valuable in that they allow for comparisons among different fuels and for the calculation of integrated summary statistics, such as the U.S. consumption of energy. The $A E R$ emphasizes domestic energy statistics.

DOE/EIA-0384(95) Annual July 1996416 pp. GPO Stock Number: 061-003-00962-0

GPO Price: $\$ 25.00$

\section{Emissions of Greenhouse Gases in the United States 1995}

This is the fourth annual report on U.S. emissions of greenhouse gases. This report presents estimates of U.S. anthropogenic (human-caused) emissions of carbon dioxide, methane, nitrous oxide, and several other greenhouse gases for 1988 through 1994. Estimates of 1995 carbon dioxide, nitrous oxide, and halocarbon emissions are also provided, although complete 1995 estimates for methane are not yet available.

DOE/EIA-0573(95) Annual Oct $1996156 \mathrm{pp}$.

GPO Stock Number: 061-003-00971-9

GPO Price: $\$ 13.00$

\section{$42 \quad$ Energy Information Sheets}

The Energy Information Sheets was developed to provide general information on various aspects of fuel production, prices, consumption, and capacity. Additional information on related subject matter can be found in other Energy Information Administration (EIA) publications as referenced at the end of each sheet.

DOE/EIA-0578(94) Annual Aug 199652 pp.

\section{International Energy Annual 1995}

The International Energy Annual (IEA) presents an overview of key international energy trends for production, consumption, imports, exports or primary energy commodities in over 220 countries, dependencies, and areas of special sovereignty. Also included are population and gross domestic product data, as well as prices for crude oil and petroleum products in selected countries. Renewable energy reported in the IEA includes hydroelectric power, geothermal, solar and wind electric power and alcohol for fuel. This report is published to keep the public and other interested parties fully informed of primary energy supplies on a global basis. The data presented have been largely derived from published sources. The data have been converted to units of measurement and thermal values familiar to the American public.

DOE/EIA-0219(95) Annual Dec 1996234 pp. GPO Stock Number: 061-003-00984-1 GPO Price: $\$ 16.00$

\section{Monthly Energy Review}

The Monthly Energy Review (MER) presents an overview of recent monthly energy statistics. The statistics cover the major activities of U.S. production, consumption, trade, stocks, and prices for petroleum, natural gas, coal, electricity, and 
nuclear energy. Also included are international energy and thermal and metric conversion factors. The $M E R$ is intended for use by Congress, Federal and State agencies, energy analysts, and the general public.

DOE/EIA-0035 Monthly GPO Subscription Price: $\$ 87.00$

\section{The National Energy Modeling System: An Overview}

The National Energy Modeling System: An Overview (Overview) provides a summary description of the National Energy Modeling System (NEMS), which was used to generate the forecasts of energy production, demand, imports, and prices through the year 2015 for the Annual Energy Outlook 1996 (AEO96), (DOE/EIA0383(96)), released in January 1996. The AEO96 presents national forecasts of energy markets for five cases--a reference case and four additional cases that assume higher and lower economic growth and higher and lower world oil prices than in the reference case. The Overview presents a brief description of the methodology and scope of each of the component modules of NEMS. The model documentation reports listed in the appendix of this document provide further details.

DOE/EIA-0581(96) One-Time Mar 199660 pp. GPO Stock Number: 061-003-00955-7

GPO Price: $\$ 4.25$

\section{Performance Profiles of Major Energy Producers 1994}

The purpose of this publication is to examine developments in the operations of the major U.S. energy-producing companies on a corporate level, by major line of business, by major function within each line of business, and by geographic area. This report presents data collected on Form EIA-28 for the calendar year 1994. In 1994, 24 companies filed Form EIA-28. The analysis and data presented in this report represent the operations of the Financial Reporting System (FRS) companies in the context of their worldwide operations and in the context of the major energy markets which they serve. Both energy and nonenergy developments of these companies are analyzed. Although the focus is on developments in 1994, important trends prior to that time are also featured. Economic performance, in financial and physical dimensions, continues to serve as a significant factor in evaluating past decisions and guiding future options in the development and supply of energy resources. The information contained in this report is intended to promote an understanding and provide a critical review of the possible motivations and apparent consequences of investment decisions by some of the largest corporations in the energy industry. The information is intended for use by the U.S. Congress, Government agencies, industry analysts, and the general public.

DOE/EIA-0206(94) Annual Jan $1996156 \mathrm{pp}$. GPO Stock Number: 061-003-00951-4

GPO Price: $\$ 11.00$

\section{Privatization and the Globalization of Energy Markets}

This report discusses recent efforts at privatization in petroleum, electricity, and coal, as well as the impetus that privatization has provided in fostering the evolution of the multinational and multidimensional energy company. Of particular note: (1) Privatization in such countries as the Former Soviet Union, and other formerly-socialist nations, has clearly widened the scope of the major petroleum companies to include previously off-limit exploration and development areas; (2) Privatization has also fomented the greater integration of traditional petroleum companies into electric power, and the convergence of the electric power and natural gas industries. There 
are both geographic and energy specific dimensions to privatization, both of which have served to form the outline of this report.

DOE/EIA-0609 One-Time Oct $1996116 \mathrm{pp}$. GPO Stock Number: 061-003-00973-5

GPO Price: $\$ 13.00$

\section{$48 \quad$ State Energy Data Report 1994 Consumption Estimates}

The State Energy Data Report 1994 (SEDR 1994) provides annual time series estimates of Statelevel energy consumption by major economic sector. The estimates are developed in the State Energy Data System (SEDS), which is maintained and operated by the Energy Information Administration (EIA). The goal in maintaining SEDS is to create historical time series of energy consumption by State that are defined as consistently as possible over time and across sectors. SEDS exists for two principal reasons: (1) to provide State energy consumption estimates to Members of Congress, Federal and State agencies, and the general public; and (2) to provide the historical series necessary for EIA's energy models. The SEDR 1994 presents estimates of annual energy consumption at the State and national levels by major economic sector and by principal energy type for 1960 , 1965 , and 1970 through 1994. Included in the report are documentation describing how the estimates were made for each energy source, the sources of all input data, and a summary of changes from the State Energy Data Report published in July 1995.

DOE/EIA-0214(94) Annual Oct 1996552 pp. GPO Stock Number: 061-003-00972-7

GPO Price: $\$ 44.00$

\section{Voluntary Reporting of Greenhouse Gases 1995}

The Voluntary Reporting Program for greenhouse gases is part of an attempt by the U.S. Government to develop innovative, low-cost, and nonregulatory approaches to limit emissions of greenhouse gases. It is one element of an array of such programs introduced in recent years as part of the effort being made by the United States to comply with its national commitment to stabilize emissions of greenhouse gases under the Framework Convention on Climate Change. The Voluntary Reporting Program, developed pursuant to Section 1605(b) of the Energy Policy Act of 1992, permits corporations, government agencies, households, and voluntary organizations to report to the Energy Information Administration (EIA) on actions taken that have reduced or avoided emissions of greenhouse gases. The first reporting year for the Voluntary Reporting Program was 1995. A total of 108 reports were received, encompassing some 645 individual emissions reduction projects, and 40 reports of "entity-level" greenhouse gas emissions, attributable to an entire organization. Emissions of greenhouse gases reported to the program account for about 23 percent of U.S. national carbon dioxide emissions. Reports received cover annual emissions from 1987 to 1994 and annual reductions claimed between 1991 and 1994.

DOE/EIA-0608(95) One-Time Jul 199684 pp. GPO Stock Number: 061-003-00965-4 GPO Price: $\$ 5.50$ 


\section{End-Use Consumption}

\section{Energy Consumption Series Residential Energy Consumption Survey Quality Profile}

The Residential Energy Consumption Survey (RECS) is a triennial national survey that provides timely information about energy consumption and expenditures of U.S. households and about energy-related characteristics of housing units. The purpose of this RECS Quality Profile is to present, in a convenient form, a report on what has been learned about the quality of RECS data since the survey began. In a broad sense, the term "quality" covers the relevance, timeliness, and accuracy of the survey estimates. The emphasis here will be placed on "accuracy." The report provides information about sampling and nonsampling errors, focusing on the latter. It discusses the types and sources of errors that occur and their possible effects on interpretation of RECS data, especially when used for longitudinal analysis. This information should be helpful to users of RECS data, to those responsible for the design and operation of the survey, and to persons with general interest in survey design and data quality.

DOE/EIA-0555(96)/1 One-Time Mar 1996 192 pp. GPO Stock Number: 061-003-00956-5 GPO Price: $\$ 12.00$

\section{Energy Consumption Series Residential Lighting: Use and Potential Savings}

The 1993 Residential Consumption Survey (RECS) was the first to permit the estimation of annual kilowatthours (kWh) used for lighting. The survey contained more detailed questions about the number of indoor lights used for specific amounts of time and more detailed questions about the use of outdoor lights than did previous surveys. In addition to these basic questions on the Household Questionnaire, the 1993 RECS also included a supplementary questionnaire, administered to a subset of households, that contained more detailed information about the types of lights used in the household, the rooms in which they were located, and the amount of time they were used. The Detailed Tables in this report contain data from both the Household Questionnaire and the Lighting Supplement Questionnaire. The RECS sample was designed to represent the entire U.S. population of residential households. Consequently, tables that are compiled from the Household Questionnaire include weighted data. On the other hand, the main purpose behind the Lighting Supplement Questionnaire was to gather enough representative data to develop a household-level model of lighting consumption. Therefore, data from the Lighting Supplement are not weighted and represent only the households that participated in the Lighting Supplement.

DOE/EIA-0555(96)/2 One-Time September 199688 pp. GPO Stock Number: 061-00300969-7 GPO Price: $\$ 6.50$

\section{Models}

\section{Documentation of the Oil and Gas Supply Module (OGSM)}

The purpose of this report is to define the objectives of the Oil and Gas Supply Model (OGSM), to describe the model's basic approach, and to provide detail on how the model works. This report is intended as a reference document to model analysts, users, and the public. It is 
prepared in accordance with the Energy Information Administration's (EIA) legal obligation to provide adequate documentation in support of its statistical and forecast reports (Public Law 93-275, Section 57(b)(2)).

DOE/EIA-M063(96) One-Time Jan 1996216 pp.

\section{Electricity Market Module Electricity Capacity Planning Submodule - Updates for AEO 1996}

The purpose of this report is to describe modifications to the Electricity Capacity Planning Submodule (ECP) for the Annual Energy Outlook 1996. It describes revisions to enhance the representation of planned maintenance, incorporate technological improvements in operating efficiencies, revise the algorithm for determining international firm power imports, and include risk premiums for new plant construction.

DOE/EIA-M068-B/2 One-Time Jun 199618 pp.

\section{Electricity Market Module Electricity Finance and Pricing Submodule - Updates for AEO 1996}

The purpose of this report is to document the updates to the Electricity Financial Pricing Module (EFP) to reflect the rate impacts of nuclear decommissioning. The EFP is part of the National Energy Modeling System (NEMS). The updates to the EFP related to nuclear decommissioning include both changes to the underlying data base and the methodology.

DOE/EIA-M068-C/1 One-Time Jun 199616 pp.

$\begin{array}{llr}\text { Electricity } & \text { Market } & \text { Module } \\ \text { Electricity } & \text { Fuel } & \text { Dispatch } \\ \text { Submodule } & - \text { Updates } & \text { for } \text { AEO } \\ 1996 & & \end{array}$

In previous Annual Energy Outlooks (AEO), international electricity trade was represented in the National Energy Modeling System (NEMS) Electricity Market Module (EMM) modeling framework as an exogenous input. The exception to this exogenous treatment was for firm power projections, i.e., new Canadian hydroelectric model builds. The AEO95 implementation of EMM allowed Canadian hydroelectric projects to be selected in the Electricity Capacity Planning (ECP) submodule on an annual basis and otherwise addressed as any other purchased power commitments. This technical memorandum addresses modifications to the Electricity Fuel Dispatch Submodule implemented in the AEO96 to enhance the treatment of international electricity trade through the representation of economy imports from Canada.

DOE/EIA-M068-D/1 One-Time Jun 19966 pp.

\section{EIA Model Documentation: Petroleum Market Model of the National Energy Modeling System}

The purpose of this report is to define the objectives of the Petroleum Market Model (PMM), describe its basic approach, and provide detail on how it works. This report is intended as a reference document for model analysts, users, and the public. Documentation of the model is in accordance with the Energy Information Administration's (EIA's) legal obligation to provide adequate documentation in support of its models (Public Law 94-385, Section 57(b)(2). The PMM models petroleum refining activities, the marketing of petroleum products to consumption regions, the production of natural gas liquids in gas processing plants, and domestic 
methanol production. The PMM projects petroleum product prices and sources of supply for meeting petroleum product demand. The sources of supply include crude oil, both domestic and imported; other inputs including alcohols and ethers; natural gas plant liquids production; petroleum product imports; and refinery processing gain. In addition, the PMM estimates domestic refinery capacity expansion and fuel consumption. Product prices are estimated at the Census Division level and much of the refining activity information is at the Petroleum Administration for Defense (PAD) District level.

DOE/EIA-M059(96) One-Time Mar 1996 $292 \mathrm{pp}$.

\section{Model Documentation Coal Market Module of the National Energy Modeling System}

This report documents the objectives and the conceptual and methodological approach used in the development of the National Energy Modeling System's (NEMS) Coal Market Module (CMM) used to develop the Annual Energy Outlook 1996 (AEO96). This report catalogues and describes the assumptions, methodology, estimation techniques, and source code of CMM's three submodules. These are the Coal Production Submodule (CPS), the Coal Export Submodule (CES), and the Coal Distribution Submodule (CDS). This document has three purposes. It is a reference document providing a description of CMM for model analysts and the public. It meets the legal requirement of the Energy Information Administration (EIA) to provide adequate documentation in support of its statistical and forecast reports (Public Law 93-275, Federal Energy Administration Act of 1974, Section 57(b)(1), as amended by Public Law 94-385). Finally, it facilitates the continuity in model development by providing documentation from which energy analysts can undertake model enhancements, data updates, and parameter refinements as future goals to improve the quality of the module.

DOE/EIA-M060(96) One-Time Apr 1996 $186 \mathrm{pp}$.

\section{Model Documentation Natural Gas Transmission and Distribution Model of the National Energy Modeling System - Volume I}

The Natural Gas Transmission and Distribution Model (NGTDM) is the model within the National Energy Modeling System (NEMS) that represents the transmission, distribution, and pricing of natural gas. The model also includes representations of the end-use demand for natural gas, the production of domestic natural gas, and the availability of natural gas traded on the international market based on information received from other NEMS models. The NGTDM determines the flow of natural gas in an aggregate, domestic pipeline network, connecting domestic and foreign supply regions with 12 demand regions. The methodology employed allows the analysis of impacts of regional capacity constraints in the interstate natural gas pipeline network and the identification of primary pipeline capacity expansion requirements. There is explicit representation of core and noncore markets for natural gas transmission and distribution services, and the key components of pipeline tariffs are represented in a pricing algorithm. Natural gas pricing and flow patterns are derived by obtaining a market equilibrium across the three main elements of the natural gas market: the supply element, the demand element, and the transmission and distribution network that links them. The NGTDM consists of four modules: the Annual Flow Module, the Capacity Expansion Module, the Pipeline Tariff Module, and the Distributor Tariff Module. This report documents the archived version of the NGTDM that was used to produce the natural gas forecasts used in support of the Annual Energy Outlook 
1996, DOE/EIA-0383(96). The purpose of this report is to provide a reference document for model analysts, users, and the public that defines the objectives of the model, describes its basic design, provides detail on the methodology, and describes the model inputs, outputs, and key assumptions.

DOE/EIA-M062/1(96) One-Time Feb 1996 $254 \mathrm{pp}$.

\section{Model Documentation Renewable Fuels Module of the National Energy Modeling System}

This report documents the objectives, analytical approach, and design of the National Energy Modeling System (NEMS) Renewable Fuels Module (RFM) as it relates to the production of the Annual Energy Outlook 1996 (AEO96) forecasts. The report catalogues and describes modeling assumptions, computational methodologies, data inputs, and parameter estimation techniques. A number of offline analyses used in lieu of RFM modeling components are also described. This documentation reports serves two purposes. First, it is a reference document for model analysts, model users, and the public interested in the construction and application of the RFM. Second, it meets the legal requirement of the Energy Information Administration (EIA) to provide adequate documentation in support of its models (Public Law 93-275, Federal Energy Administration Act of 1974, Section 57(b)(1)). Such documentation facilitates continuity in EIA model development by providing information sufficient to perform model enhancements and data updates as part of EIA's ongoing mission to provide analytical and forecasting information systems.

DOE/EIA-M069(96) One-Time Apr 1996 $196 \mathrm{pp}$.

\section{Model Documentation Report Short-Term Hydroelectric Generation Model}

The purpose of this report is to define the objectives of the Short-Term Hydroelectric Generation Model (STHGM), describe its basic approach, and provide details on the model structure. This report is intended as a reference document for model analysts, users, and the general public. Documentation of the model is in accordance with the EIA's legal obligation to provide adequate documentation in support of its models (Public Law 94-385, Section 57(b)(2)). The STHGM performs a short-term (18 to 27 month) forecast of regional (Census Division) hydroelectric generation in the United States using an autoregressive integrated moving average (ARIMA) time series model with precipitation as an explanatory variable. The model results are used as input for the Short-Term Energy Outlook.

DOE/EIA-M053(96) One-Time Dec 199654 pp.

\section{Forecasting}

\section{An Analysis of Carbon Mitigation Cases}

This study was undertaken at the request of the U.S. Environmental Protection Agency, Office of Air and Radiation (EPA/OAR). Its purpose is to analyze the potential of rapid technological improvements and rapid rates of technology adoption in U.S. energy markets to reduce carbon emissions. Three analytical cases, based on different sets of assumptions, were specified by EPA/OAR for the study, incorporating the use of technologies that are significantly more efficient than those in general use today. The analysis described in this report was produced by using the National Energy Modeling System (NEMS). 
NEMS is an integrated energy-economy modeling system for U.S. energy markets, developed by the EIA as a policy analysis tool to provide an integrated framework for policymakers to understand the implications of proposed policies and alternative assumptions concerning energy markets.

DOE/EIA-SR/OIAF/96-01 One-Time Jun 1996 $446 \mathrm{pp}$.

\section{Annual Energy Outlook 1996}

The Annual Energy Outlook 1996 (AEO96) presents midterm energy forecasts by the Energy Information Administration (EIA). This year's report presents projections and analyses of energy supply, demand, and prices through 2015 , based on results from EIA's National Energy Modeling System (NEMS). AEO96 is the first Annual Energy Outlook with forecasts extended to 2015. The $A E O 96$ projections are used by Federal, State, and local governments, trade associations, and other planners and decisionmakers in the public and private sectors. They are published in accordance with Section 205C of the Department of Energy Organization Act of 1977 (Public Law 95-91), which requires the Administrator of EIA to prepare an annual report that contains trends and projections of energy consumption and supply.

DOE/EIA-0383(96) Annual Jan 1996288 pp. GPO Stock Number: 061-003-00947-6 GPO Price: $\$ 18.00$

\section{Annual Energy Outlook 1997}

The Annual Energy Outlook 1997 (AEO97) presents midterm forecasts of energy supply, demand, and prices through 2015 prepared by the Energy Information Administration (EIA). These projections are based on results of EIA's National Energy Modeling System (NEMS). This report begins with a summary of the reference case, followed by a discussion of the legislative assumptions and evolving legislative and regulatory issues. "Issues in Focus" discusses emerging energy issues and other topics of particular interest. It is followed by the analysis of energy market trends. The $A E O 97$ projections are used by Federal, State, and local governments, trade associations, and other planners and decisionmakers in the public and private sectors. They are published in accordance with Section 205@ of the Department of Energy Organization Act of 1977 (Public Law 95-91), which requires the Administrator of EIA to prepare an annual report that contains trends and projections of energy consumption and supply.

DOE/EIA-0383(97) Annual Nov 1996232 pp. GPO Stock Number: 061-003-00978-6

GPO Price: $\$ 19.00$

\section{International Energy Outlook 1996}

The International Energy Outlook 1996 (IEO96) presents an assessment by the Energy Information Administration (EIA) of the outlook for international energy markets through 2015 . The report is an extension of the EIA's Annual Energy Outlook 1996 (AEO96), which was prepared using the National Energy Modeling System (NEMS). U.S. projections appearing in the IEO96 are consistent with those published in the AEO96. IEO96 is provided as a statistical service to energy managers and analysts, both in government and in the private sector. The projections are used by international agencies, Federal and State governments, trade associations, and other planners and decisionmakers. They are pursuant to the Department of Energy 
Organization Act of 1977 (Public Law 95-91, Section 205(c)). The IEO96 projections are based on U.S. and foreign government policies in effect on October 1, 1995.

DOE/EIA-0484(96) Annual April 1996 148 pp. GPO Stock Number: 061-003-00957-3 GPO Price: $\$ 7.00$

\section{Issues in Midterm Analysis and Forecasting 1996}

Issues in Midterm Analysis and Forecasting 1996 (Issues) presents a series of five papers, which cover topics in analysis and modeling that underlie the Annual Energy Outlook 1996 (AEO96). The AEO96 (DOE/EIA-0383(96)), published in January 1996, presents national forecasts of energy production, demand, imports, and prices through the year 2015. The AEO96 includes forecasts of energy markets for five cases--a reference case and four additional cases that assume higher and lower economic growth and higher and lower world oil prices than in the reference case. The forecasts are generated using the Energy Information Administration's (EIA) National Energy Modeling System (NEMS). The papers included in Issues are intended to describe underlying analyses for the projections in the $A E O 96$ and other analytical products. This provides public access to analytical work done in preparation for the $A E O 96$ and to other unpublished analyses. Specific topics were chosen for their relevance to current energy issues or to highlight modeling activities in NEMS.

DOE/EIA-0607(96) One-Time Aug 1996 128 pp. GPO Stock Number: 061-003-00963-8 GPO Price: $\$ 7.50$

\section{Short-Term Energy Outlook Quarterly Projections}

The Short-Term Energy Outlook Quarterly Projections (STEO) presents quarterly forecasts of energy supply, demand, stocks, and prices for each quarter. The forecasts are produced by using the Short-Term Integrated Forecasting System, which uses two principal driving variables, a macroeconomic forecast and world oil price assumptions. The three projections for petroleum supply and demand are based on low, middle, and high economic growth scenarios that incorporate high, middle and low crude oil price trajectories. The tables and discussion refer primarily to the middle, or base case, scenario and to the domestic situation. Other cases which examine the sensitivity of total petroleum demand to varying assumptions about prices, weather, and economic activity are presented. The petroleum outlook includes data projections of domestic crude oil production, motor gasoline, distillate fuel oil, residual fuel oil, and other products and inventories. Also included are natural gas, coal and electric power projections. Additionally, the international petroleum situation is discussed.

DOE/EIA-0202 Quarterly GPO Subscription Price: $\$ 19.00$ 



\section{Energy Information Administration's Products and Services}

\section{Electronic Publishing System (EPUB)}

EPUB is an electronic publishing system maintained by EIA. EPUB allows the general public to electronically access selected energy data from many of EIA's statistical reports. The system is a menu-driven, bulletin-board-type system with extensive online help capabilities that can be accessed free of charge 24 hours a day by use of a terminal or PC with an asynchronous modem. (EPUB will be taken down briefly at midnight, eastern time, for backup.)

PC users must provide the following information to their communications software in order to successfully access the EPUB system:

Communications Parameters:

Baud Rate: Up to 28,800 bps

Data Bits: 8; Stop Bits: 1

Parity: None; Duplex: Full

Terminal Type: ANSI, ANSI-BBS, VT100, etc.

Once communications software and/or hardware have been configured, EPUB can be accessed by dialing (202) 586-2557. When a connection to the system has been made, some users may find that the menu-driven instructions and the online capabilities will provide enough information to effectively use EPUB. More information may be obtained from:

National Energy Information Center, EI-30

Energy Information Administration

Forrestal Building, Room 1F-048

Washington, DC 20585

(202) 586-8800
Internet E-Mail: infoctr@eia.doe.gov

TTY: For people who are deaf or hard of hearing: (202) 586-1181

Hours: 9 a.m. to 5 p.m., M-F, eastern time

For communications or technical assistance, call (202) 586-8959, 8 a.m. to 5 p.m., eastern time, Monday through Friday. For questions about the contents of EPUB reports and data, call (202) 586-8800, 9 a.m. to 5 p.m., eastern time, Monday through Friday.

Following is a listing of some of the data and reports that are provided on EPUB:

\section{Coal, Nuclear, and Alternate Fuels}

Weekly Coal Production Report (WCPR). Statistics on U.S. production of bituminous coal and lignite and the production of Pennsylvania anthracite are provided for each of the two most recent weeks, for a corresponding week in the previous year, and for the prior 52-week period and the corresponding period in the previous year, with percentage changes. Total U.S. production and the number of railroad cars loaded are also reported.

Updated on Fridays at 5 p.m.

Quarterly Coal Report (QSCR). Statistics on U.S. coal production, consumption, exports and imports, and stocks are provided by quarter for the most recent quarter and for previous years. Consumption and stocks are reported by end-use sector, and annual production trends are reported by State.

Updated 60 days after the end of the quarter. 


\section{Oil and Gas}

\section{Heating Fuel Data (HFUL).}

Heating fuel data contain the most recent weekly/monthly data on production, imports, stocks, and residential and wholesale prices for residential heating fuels.

Updated every Thursday at 5 p.m., October through March, and the second week of the month April through September.

Oxygenate Data (OXYDATA). Statistics by month on fuel ethanol, methyl tertiary butyl ether (MTBE), and methanol production, stocks, and amount blended into motor gasoline are reported. Data are by PAD District and for the total United States.

Updated approximately 15 working days after the end of the month.

Weekly Petroleum Status Report (WPSR). The latest U.S. petroleum balance sheet and the last five weeks of Weekly Petroleum Status Report data are reported. Data include domestic crude oil production, petroleum imports and exports, crude input to refineries, petroleum products supplied for consumption, and petroleum stocks.

Updated on Wednesdays (Thursdays in event of holidays) at 9 a.m., eastern time.

PSM State Stocks (STKS). The most recent month's data on refinery, bulk terminal, and natural gas plant stocks of selected petroleum products (product specific) by PAD District and State are reported.

Updated on the 20th of the month.

Petroleum Marketing Report (PMMR). Statistical data for the current three months and the reference month one year ago on crude oil and petroleum product prices and sales volumes are reported. Data are for the United States and by PAD District.

Updated on the 20th of the month.
Weekly On-Highway Diesel Prices (DIESLPRC). Weekly data by U.S. average and PAD District of the retail, on-highway, self service, cash price (including taxes) of diesel fuel are included. Prices are historical back to March 21, 1994.

Updated on Monday at 5:00 p.m, eastern time.

Weekly Retail Gasoline Prices (GASOLINE). Weekly data by U.S. average and PAD District of retail, unleaded regular, self service, cash price (including taxes) for motor gasoline are included. Updated on Tuesday at 5:00 p.m., eastern time.

Natural Gas Monthly (NGMR). Data for the most recent five months on natural gas supply and disposition and prices are reported. Data are at the national level for supply and disposition, consumption by consuming sector and price, and at the State level for end-use sector deliveries and price to end users.

Updated on the 20th of the month.

\section{Energy Forecasts}

Short-Term Energy Outlook (STEO). Quarterly forecasts for the next four quarters of the U.S. energy supply and demand summary; forecast assumptions; international petroleum balance; energy prices; domestic supply and disposition of petroleum in low, mid, and high world oil price scenarios; and supply and disposition of natural gas, coal, and electricity for a mid world oil price scenario are reported.

Updated 60 days after the end of the quarter.

Short-Term Energy Model (STEM). The complete package (in compressed format) of EIA's Short-Term Energy Model is used to forecast supply and prices of major fuels 18 months into the future. The model allows users to 
access all forecast information used by EIA to produce its short-term projections, to change data and forecasts to percentages and graphs, and to revise forecast assumptions and recalculate the model.

\section{Updated each quarter.}

Annual Energy Outlook (AEO). The projection cases from the Annual Energy Outlook are presented. These tables are the tables given in Appendices A through $\mathrm{E}$ of the publication, Annual Energy Outlook.

Updated annually.

Monthly Energy Review (MER). Statistics on current U.S. total energy summaries and key data series for production, consumption, stocks, imports, exports, and prices of the individual energy commodities are presented. Most of the data series are from 1973 forward. Also included are data on the international production of crude oil, consumption of petroleum products, petroleum stocks, and production of electricity from nuclear power facilities. All data tables from the Monthly Energy Review, including the Btu conversion factors, are included.

Updated the last week of the month.

\section{EIA Press Releases}

The full text of the latest press releases from EIA is included.

Updated as new press releases are issued.

\section{EIA Publications Directory}

Publications Directory. The text of the EIA Publications Directory includes abstracts of the publications produced during the given year. Updated annually when the publication is released.

\section{EIA New Releases}

New Releases (NEWREL). The text of the current quarterly newsletter lists and describes recently released EIA publications.

Updated quarterly.

\section{Monthly Petroleum Imports}

Contains monthly data for the current reporting year and annualized data for the prior reporting years on crude oil and petroleum product imports into the United States. Data include the name of the importer of record, commodity imported, port of entry, quantity imported, percent sulfur by weight, API gravity, and processing company and location.

Updated monthly.

\section{Financial Reporting System}

Contains tables from EIA's Performance Profiles of Major Energy Producers on operating statistics, profit ratios, balance sheet, cash flows, income taxes, U.S. well completions, development and production expenses, refining statistics, research and development expenses, and coal reserves and production. Data are aggregated for all companies reporting under EIA's Financial Reporting System.

Updated annually.

\section{Energy Information Contacts}

Contains names and telephone numbers of subject matter contacts for inquiries on EIA data, forecasts, and statistical standards and methods. Updated annually/as needed. 


\section{Electric Power Monthly}

Summary electric utility statistics at the national and State level on net generation, fossil fuel consumption, fossil fuel stocks, sales, revenue, average revenue per kilowatthour sold, and fossil fuel receipts for the most recent month, the corresponding month for the previous year, and for the prior month are reported. Generation, consumption, receipts, and stocks are fuel specific; and sales, revenue, and average revenue are specific to end-use sector. Forty-four of the 64 publication tables are included.

Updated on the 1st of the month.

\section{Petroleum Supply Monthly}

Statistical data on the U.S. daily average supply and disposition of petroleum; crude oil production by State and PAD District; imports of petroleum into the United States by country of origin; and petroleum stocks by PAD District are reported. Data are primarily for the most recent month. Most of the tables reported in the Petroleum Supply Monthly are included.

Updated between the 23rd and 26th of the month.

\section{Internet}

Inquiries can be sent to NEIC on the Internet. NEIC's E-Mail address is: infoctr@eia.doe.gov. PC users must provide the following information in their E-Mail message: name, affiliation and address, daytime telephone number, fax number, and E-Mail address. NEIC will choose the best medium to respond to an inquiry as quickly as possible.

\section{EIA's World Wide Web Site}

EIA's World Wide Web site provides access to information on energy consumption, production, and prices; statistical and economic analyses; forecasts of short-term and midterm energy supply, demand, and prices; and other factors relating to the energy sector. There are fuelspecific databases that can be downloaded for use in spreadsheet and database programs. Voluminous data on supply, disposition, and prices of the major energy fuel/sources are presented in database format. Modeling applications that can be used to replicate the short-term and midterm forecasting EIA produces for the Short-Term Energy Outlook and the Annual Energy Outlook are also available for downloading. The World Wide Web address is:

$$
\text { http://www.eia.doe.gov }
$$

Internet users can also visit EIA's FTP server (ftp://ftp.eia.doe.gov) and EIA's gopher site (gopher://gopher.eia.doe.gov) to access a variety of data files and reports.

Additional components of the site are:

- The most recent EIA press releases

- A section of most frequently asked general and most frequently asked technical questions

- A sign-up form for the EIA e-mail list subscriber service

- The EIA Government Information Locator Service (GILS) records

- An energy events calendar 
An interactive query facility permitting users to generate customized output from EIA's data bases

- Hypertext links to other useful energy information sites

\section{Listserve}

EIA's Internet electronic mail (e-mail) subscription service (commonly called a listserve) disperses electronic documents--weekly, monthly, quarterly, and occasionally--to an e-mail subscriber list. Documents include press releases, market reports, fuel watches, price data, and publication summaries.

\section{Energy InfoDisc}

EIA released its new CD-ROM, Energy InfoDisc, in February 1996. The Energy InfoDisc is EIA's latest electronic offering as the agency strives to increase the timeliness and usability of its information products. This new compendium of EIA's national energy databases, publications, directories, and software applications brings EIA's comprehensive collection of energy information to users' fingertips.

Using CD-ROM technology, the Energy InfoDisc provides easy and inexpensive access to EIA's historical time series for production, consumption, prices, and resource availability of conventional and alternate energy resources; analyses of economic and technical topics; and projections of future energy supply, demand, and prices.

The Energy InfoDisc allows the user to view and search more than 200 data, analysis, and forecasting reports and directories published over the previous 12 months. In addition, users can access EIA's extensive energy databases and specialized applications to generate their own individualized energy databases. Each issue highlights new products and any changes or enhancements to the CD. The Energy InfoDisc provides information about EIA's mission and goals as the primary source of statistical energy information to the public and provides a directory of EIA's energy experts by area of expertise. Contacts for other Federal statistical programs are also included.

The CD features the Monthly Energy Review; Short-Term, Annual, and International Energy Outlooks; Natural Gas: Issues and Trends; Electric Power and Renewable Energy Annuals; and EIA New Releases, among many other EIA reports and directories. The Energy InfoDisc also contains EIA's Monthly Energy Review; oil and gas information; and coal, nuclear, and electricity databases and popular applications, including Short-Term Energy Forecasts, State Energy Data System, and World Energy.

EIA databases containing monthly and annual time series cover most aspects of energy supply and demand. Energy analysis applications allow users to examine selected aspects of EIA energy data, analyses, and forecasts and to display or tabulate the data in other ways for their own analysis.

Publications and directories are displayed in Portable Document Format (PDF); the Energy InfoDisc includes free Adobe Acrobat software for viewing and searching these documents. Most of the energy database applications are written in Microsoft Access. The Microsoft Access run-time engine required for these applications is also included.

The Energy InfoDisc is issued quarterly. The single issue price in the United States, Canada, and Mexico is $\$ 45$. Outside these areas, the price per issue is $\$ 60$. An annual subscription of four quarterly issues is $\$ 100$ in the United States, Canada, and Mexico and $\$ 160$ outside these areas. 
The Energy InfoDisc is distributed by STAT-USA, a U.S. Department of Commerce information service for business, economic, and trade professionals, through a cooperative agreement with EIA. To order, call 1-800STAT-USA, or (202) 482-1986. To find out more about the Energy InfoDisc and its contents, contact NEIC by phone: (202) 586-8800 or by Internet E-Mail: infoctr@eia.doe.gov. 


\section{Subject Index}

(Numbers following entries refer to abstract numbers)

Alternative fuels 37, 38, 39

Annual Report to Congress 1

Coal

coal market model $\mathbf{5 7}$

consumption 9,10

distribution 9, 10

exports $\mathbf{1 0}$

financial statistics 46

imports 9,10

industry overview 9

prices 9,10

production 9,10

productivity 9

reserves 11

stocks 10

Coke

exports $\mathbf{1 0}$

imports 10

production 10

Commercial buildings

energy consumption $\mathbf{4 0}$

Crude oil

exports 23, 24, 25

financial statistics 46

imports 23, 24, 25

prices 22

production $16,23,24,25$

reserves 26

stocks 23, 24, 25

Supply Model 52

transportation $23,24,25$

Degree-days 27, 40, 44

Directories

educational materials 8, 42

electronic products 5

models 4

publications 6,7
Educational materials 8, 42

Electricity

demand-side management 33,34

environmental statistics 33,34

financial statistics 33, 34

fuel consumption 33,35

fuel costs 35

generating capability $33,34,35$

generation 32, 33, 35, 36

nonutility generators 34

prices 33

revenues 33

sales 33

Electronic products

directory 5

Emissions

carbon 61

electric utilities $32,34,36$

greenhouse gases 38, 41, 49

Energy industry

financial statistics $\mathbf{4 6}$

Energy Information Administration

Annual Report to Congress 1

Ethanol

production 25,27

production capacity 23,24

stocks 25, 27

Forecasts 62, 63, 65, 66

international 64

nuclear power 28

Greenhouse gases 38, 41

International statistics $16,43,47$

expansion costs 21

forecasts 64

nuclear power 28

Models

NEMS Overview 45 
Coal Market $\mathbf{5 7}$

Directories 4

Electricity Market 53, 54, 55

Hydroelectric Generation Model 60

Natural Gas Transmission \&

Distribution 58

Oil and Gas Supply 52

Petroleum Market Model 56

Renewable Fuels 59

MTBE

production 25, 27

production capacity 23

stocks 25,27

Natural gas

consumption 18, 19

exports 19

financial aspects 17

imports 19

industry 17

pipelines 17

prices 18, 19

production $12,18,19,20$

regulation 17

reserves $\mathbf{2 6}$

storage 19

supply model $\mathbf{5 2}$

transmission 17

transmission \& distribution model $\mathbf{5 8}$

Natural gas liquids

reserves 26

New Releases 6

Nuclear power

projections $\mathbf{2 8}$

spent fuel 29

Petroleum products

consumption 14, 25, 27

exports $23,24,27$

financial statistics 46

imports 15, 23, 24, 27

Petroleum Market Model 56

prices $\mathbf{2 2}$

production $12,23,24,27$ stocks $23,24,27$

transportation 23, 24

Projections 62, 63, 66

international 64

nuclear power 28

Publications

directories 6, 7

Residential sector

energy consumption $\mathbf{5 0}$

lighting 51

State energy consumption 48

Transportation fuels

alternative fuels $13,37,38,39$

Uranium

imports 30,31

industry 30

prices 30, 31

production 30

purchases 31

spent fuel 31 


\section{How to Order from the National Energy Information Center}

Subscriptions and current in-stock single issues are available free of charge from NEIC for the following users: Government, news media, public and academic libraries, and EIA's survey respondents.

Call (202) 586-8800 (or TTY: (202) 586-1181)) for more information or use the NEIC Order Form (see page 32). This form is also used for change of address, for deleting a name from the NEIC mailing list, or for ordering free publications.

\section{NOTICE}

Prices of EIA publications sold by the U.S. Government Printing Office (GPO) and the National Technical Information Service (NTIS) are subject to change without notice.

When EIA publications are discontinued and consolidated into other reports, the individuals who received copies of the terminated publication through the EIA mailing list are automatically placed on the mailing list for the new publication. Subscribers to discontinued, paid publications through GPO are generally sent refunds for any balance remaining on their subscription. For further information about paid subscriptions, please contact GPO at (202) 512-1800. 


\section{NEIC Orders}

\section{NATIONAL ENERGY INFORMATION CENTER ORDER FORM}

\section{TO ORDER FREE PUBLICATIONS--TO NOTIFY NEIC OF CHANGE OF ADDRESS --TO CANCEL A MAILING LIST PUBLICATION}

Mail to: National Energy Information Center, El-30 Energy Information Administration

Room 1F-048, Forrestal Building

Washington, DC 20585

Name

Business Affiliation

Mail List I.D. Number (found in upper left corner of your mailing label)

\section{Address}

City and State Zip Code Phone Number with area code
Fax Number

$\square \quad$ Change of address.

$\square \quad$ Add name to mailing list for free publication(s) as listed below.

$\square \quad$ Take name off mailing list for publication(s) as listed below.

$\square \quad$ Send the free publication(s) as listed below.

Number of Copies 